\title{
JENIS DAN KELIMPAHAN BENIH LOBSTER (PANULIRUS spp.) BERDASARKAN KEDALAMAN DI PERAIRAN DESA RANOOHA RAYA, KECAMATAN MORAMO, KABUPATEN KONAWE SELATAN
}

\section{Types and Abundance of Lobster Larvae (Panulirus Spp.) Based on Water Depth in Ranooha Raya Village Waters, Moramo Sub-District, South Konawe Regency}

\author{
Ayu Wandira ${ }^{1}$, Muhammad Ramli ${ }^{2}$, Halili $^{3}$ \\ ${ }^{1}$ Mahasiswa Ilmu Kelautan \\ Fakultas Perikanan dan Ilmu Kelautan Universitas Halu Oleo \\ Jl. HEA Mokodompit Kampus Bumi Tridharma Anduonohu Kendari 93232 \\ ${ }^{2}$ Surel: muh.ramli@gmail.com \\ ${ }^{3}$ Surel: halili_99@yahoo.com
}

\begin{abstract}
Abstrak
Benih lobster merupakan stadia post larva yang bentuknya sudah menyerupai lobster dewasa namun belum memiliki pigmen dan rangka luar yang keras kemudian bersifat planktonis dan melayang-layang dalam air. Penelitian ini bertujuan untuk mengetahui kelimpahan benih lobster (Panulirus spp.), hubungan kelimpahan benih lobster dengan kedalaman serta parameter kualitas perairan. Pengambilan data dilakukan pada bulan Februari-September 2019, bertempat di Perairan Desa Ranooha Raya, Kabupaten Konawe Selatan. Pengambilan data dilakukan pada 3 titik stasiun pengamatan dengan menggunakan metode deskriptif eksploratif dan analisis data menggunakan analisis korelasi. Kelimpahan benih lobster (Panulirus spp.) diperoleh dengan menggunakan alat tangkap pocong (shelter) sedangkan pengambilan data kualitas perairan dilakukan secara in situ. Hasil penelitian menunjukkan bahwa kelimpahan benih lobster tertinggi yaitu pada stasiun II (kedalaman 4 meter) berjumlah 221 individu dan kelimpahan terendah pada stasiun I (kedalaman 6 meter) berjumlah 155 individu. Jenis benih lobster yang ditemukan yaitu jenis benih lobster mutiara (Panulirus ornatus) dan jenis benih lobster pasir (Panulirus homarus). Persentase kelimpahan relatif tertinggi yaitu jenis benih lobster mutiara sebesar 75\% dan persentase kelimpahan relatif terendah jenis benih lobster pasir sebesar 55,56\%. Hasil analisis korelasi hubungan kelimpahan benih lobster berdasarkan kedalaman diperoleh nilai hubungan yang kuat. Parameter kualitas perairan masih mendukung untuk kehidupan benih lobster seperti arus, suhu, kedalaman, kecerahan, $\mathrm{pH}$, salinitas dan DO (Dissolve Oxygen). Parameter kecepatan arus merupakan faktor yang sangat mempengaruhi keberadaan benih lobster (Panulirus spp.) di perairan.
\end{abstract}

Kata Kunci: Benih Lobster (Panulirus spp.), Kelimpahan, Kedalaman Perairan, Parameter Perairan.

\begin{abstract}
Lobster larvae is a post larval stage that looks like an adult lobster but do not have yet pigment and hard outer skeleton which is planktonic and floating in water. The purpose of this study was to determine the abundance of lobster larvae (Panulirus spp.), the relationship of lobster larvae abundance with depth and water quality parameters. Data was collected in February-September 2019 which located in the waters of Ranooha Raya Village, South Konawe. Sampling data was done in three stasions which used descriptive exploratory methods and data analysis used correlation analysis. The abundance of lobster larvae (Panulirus spp.) was obtained using pocong fishing gear (shelter), while waters quality parameters was carried out with in situ. The results showed that the highest abundance of lobster larvae was found at station II (with depth in 4 meters) totally 221 individues and the lowest abundance was found at station I (with depth in 6 meters) totally 155 individues. The types of lobster larvae that found are pearl lobster larvae (Panulirus ornatus) and sand lobster larvae (Panulirus homarus). The highest relative abundance percentage is pearl lobster larvae that is $75 \%$ and the lowest relative abundance percentage is sand lobster larvae that is $55.56 \%$. The results of correlation analysis of lobster larvae abundance based on depth obtained a strong relationship value. Waters quality parameters still supported the life of lobster larvae such as current, temperature, depth, brightness, $\mathrm{pH}$, salinity and DO (Dissolve Oxygen). Current speed parameter is a factor that greatly influences the presence of lobster Larvae (Panulirus spp.) in the waters.
\end{abstract}

Keywords: Lobster Seeds (Panulirus spp.), Abundance, Water Depth, Water Quality Parameters.

\section{Pendahuluan}

Lobster laut merupakan jenis hewan invertebrata yang memiliki kulit yang keras dan tergolong dalam kelompok arthropoda. Lobster dewasa dapat ditemukan pada hamparan pasir yang terdapat spot-spot karang dengan kedalaman antara 5-100 meter, yakni lobster memiliki dua habitat dalam fase hidupnya, yaitu pantai dan lautan. Lobster akan memijah di dasar perairan laut yang berpasir dan berbatu. Telur yang dibuahi akan menetas menjadi larva yang bersifat planktonis, melayang-layang dalam air (Saputra, 2009). 
Lobster berukuran benih (fase puerulus) merupakan stadia post larva yang bentuknya sudah menyerupai lobster dewasa, namun belum memiliki pigmen dan rangka luar yang keras. Fase post larva (puerulus) mengalami pergantian kulit beberapa kali dan menjadi lobster muda/kecil dan telah memiliki kerangka luar yang keras dan berzat kapur serta tinggal di dasar perairan (Pratiwi, 2013).

Jenis dan kelimpahan benih lobster pada suatu perairan ditentukan oleh lingkungan abiotik seperti fisika-kimia air, tipe substrat, dan ketersediaan makanan. Biotik yakni pola siklus hidup, penyebaran, dan toleransi terhadap masing-masing faktor lingkungan tersebut. Faktor-faktor tersebut dapat berpengaruh terhadap kelimpahan benih lobster yang terdapat di perairan. Dimana perairan Desa Ranooha Raya memiliki potensi benih lobster yang cukup melimpah walaupun adanya aktivitas penangkapan benih lobster yang dilakukan oleh masyarakat berlangsung secara terus-menerus.

Kedalaman adalah faktor oseanografi yang membatasi masuknya penetrasi cahaya matahari yang secara langsung membatasi kehidupan organisme laut salah satunya yaitu benih lobster. Intensitas cahaya matahari akan berkurang secara cepat dan akan menghilang pada kedalaman tertentu, begitu pula temperatur dan kandungan oksigen terlarut semakin berkurang pada kedalaman tertentu sampai dasar perairan.

Perairan Desa Ranooha Raya merupakan salah satu daerah yang wilayah pesisirnya menjadi habitat bagi benih lobster (Panulirus spp.). Dimana di wilayah ini para nelayan sering melakukan penangkapan pada saat musim benih lobster berlangsung yakni bulan Mei-November. Aktivitas penangkapan benih lobster dimulai sejak tahun 2013 saat masih terdapat budidaya rumput laut, yakni pada awalnya nelayan yang secara tidak sengaja menemukan benih lobster yang menempel pada rumput laut tersebut, sehingga masyarakat berinisiatif untuk menggunakan alat tangkap pocong (shelter) sebagai salah satu media perlindungan bagi benih lobster untuk bersembunyi dari predator. Seiring dengan meningkatnya harga benih lobster dan terjadinya penurunan produktivitas budidaya rumput laut di lokasi tersebut, serta maraknya ekspor benih lobster dan tingginya hasil tangkapan sehingga permintaan benih dari negara-negara importir juga meningkat. Tujuan dari penelitian ini, yaitu untuk mengetahui jenis dan kelimpahan benih lobster berdasarkan kedalaman perairan, menganalisis hubungan jenis dan kelimpahan benih lobster berdasarkan kedalaman perairan, serta mengetahui pengaruh parameter kualitas perairan terhadap benih lobster.

\section{Bahan dan Metode}

Penelitian ini dilaksanakan pada bulan Februari-September 2019, bertempat di perairan Desa Ranooha Raya, Kecamatan Moramo, Kabupaten Konawe Selatan, Provinsi Sulawesi Tenggara (Gambar 1). Tahap survey pendahuluan dilakukan untuk mengetahui keberadaan benih lobster dan melihat kondisi lapangan, hasil dari survey ini dijadikan sebagai dasar untuk penentuan titik stasiun pengamatan.

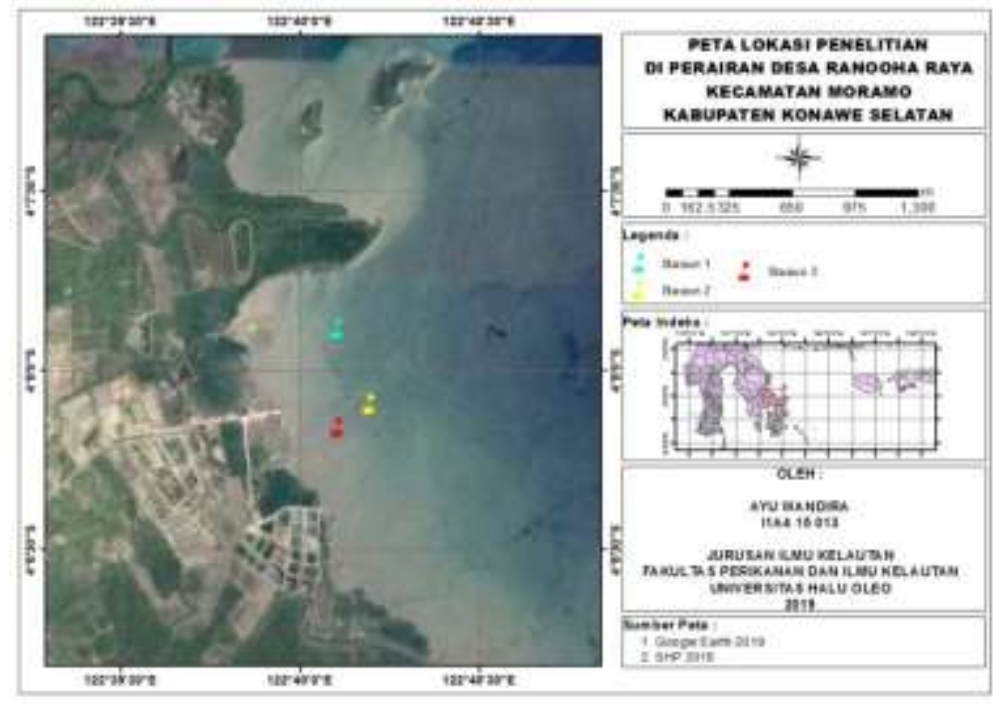

Gambar 1. Peta Lokasi Penelitian 
Tabel 1. Alat dan Bahan Beserta Kegunaannya

\begin{tabular}{|c|c|c|c|c|}
\hline No. & Alat dan Bahan & Satuan & Kegunaan & $\begin{array}{c}\text { Jumlah } \\
\text { Unit }\end{array}$ \\
\hline A. & Alat & & & \\
\hline 1. & Thermometer & ${ }^{\circ} \mathrm{C}$ & Mengukur suhu & 1 \\
\hline 2. & $\begin{array}{l}\text { Stopwatch, kompas dan } \\
\text { layangan arus }\end{array}$ & $\mathrm{m} / \mathrm{s}$ & Mengukur kecepatan arus & 1 \\
\hline 3. & Sechii disk & $\%$ & Mengukur kecerahan & 1 \\
\hline 4. & Kertas $\mathrm{Ph}$ & - & Mengukur $\mathrm{pH}$ & 1 \\
\hline 5. & Handrefraktometer & $\%$ & Mengukur salinitas & 1 \\
\hline 6. & Botol kaca & $\mathrm{mg} / \mathrm{L}$ & Mengambil sampel air & 1 \\
\hline 7. & Alat tangkap pocong & $\mathrm{m}$ & Menangkap benih lobster & 1 \\
\hline 8. & Kamera & Unit & Dokumentasi & 1 \\
\hline 9. & Alat tulis & Benda & Mencatat data & 1 \\
\hline 10. & Perahu & Benda & Alat transportasi & 1 \\
\hline 11. & Kertas label & Unit & Menandai sampel & 1 \\
\hline 12. & Toples & Unit & Wadah sampel & 1 \\
\hline 13. & Tali nilon & $\mathrm{cm}$ & Mengukur kedalaman & 1 \\
\hline B. & Bahan & & & \\
\hline 1. & $\begin{array}{l}\text { Buku identifikasi jenis lobster, } \\
\text { WWF Indonesia (2015) }\end{array}$ & - & $\begin{array}{l}\text { Mengidentifikasi jenis benih } \\
\text { lobster }\end{array}$ & 1 \\
\hline 2. & $\mathrm{MnSO}_{4}$ & $\mathrm{mg} / \mathrm{L}$ & Pengikat DO & 1 \\
\hline 3. & $\mathrm{NaN}_{3}$ & $\mathrm{mg} / \mathrm{L}$ & Pengikat DO & 1 \\
\hline
\end{tabular}

Berdasarkan survey pendahuluan yang telah dilakukan, lokasi stasiun penelitian dan penentuan stasiun dilakukan berdasarkan keberadaan benih lobster di Perairan Desa Ranooha Raya yang berdasarkan orientasi nelayan dengan menggunakan metode deskriptif eksploratif, dimana bertujuan untuk menggambarkan keadaan atau status yang ada dengan menggunakan metode alat tangkap pocong.

Stasiun pengambilan data dilakukan dengan memperhatikan keterwakilan lingkungan di lokasi. Stasiun I , daerah pecahan karang, berada pada pusat koordinat $4^{0} 7^{\prime} 56,84^{\prime \prime} \mathrm{LS}-122^{\circ} 40^{\prime} 5,23^{\prime \prime}$ BT dengan kedalaman \pm 6 meter. Stasiun II, daerah berpasir, berada pada pusat koordinat $4^{0} 8^{\prime}$ $11,19^{\prime \prime} \mathrm{LS}-122^{\circ} 40^{\prime} 11,49^{\prime \prime}$ BT dengan kedalaman \pm 4 meter. Stasiun III, daerah berlumpur, berada pada pusat koordinat $4^{0}$ $8,30^{\prime} 50^{\prime \prime}$ LS - $122^{\circ} 40^{\prime} 48^{\prime \prime}$ BT dengan kedalaman \pm 2 meter.

Alat tangkap pocong berfungsi sebagai shelter atau perlindungan bagi benih lobster, yakni benih lobster selalu mendekati suatu benda yang dapat digunakan untuk melindungi dirinya (shelter) dari predator. Adapun tahap-tahap proses pengambilan data benih lobster.
Perakitan alat tangkap pocong pertamatama menyiapkan waring, tasi, pemberat (batu), pelampung (botol plastik), tali nilon serta karung semen atau karung beras yang dibuat berbentuk kipas dan diikatkan pada waring. Selanjutnya, alat tangkap tersebut diikat menyerupai pocong pada bagian atas waring dan diberikan pemberat (Gambar 2).

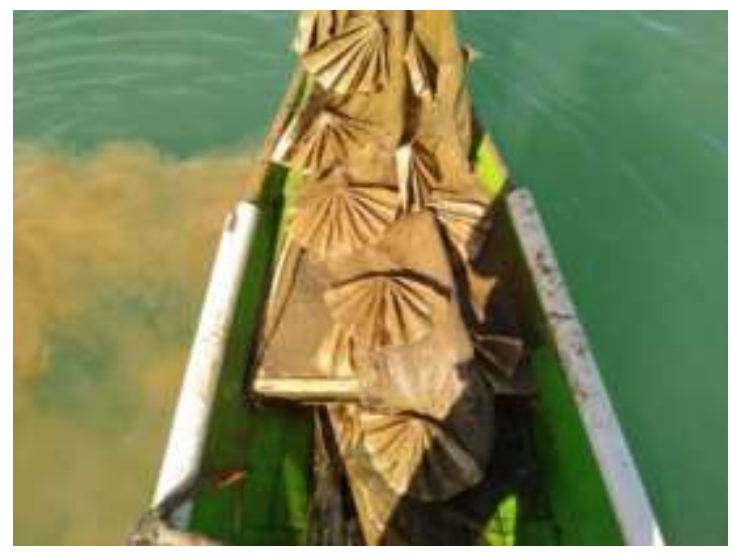

Gambar 2. Alat Tangkap Pocong (Shelter)

Alat yang sudah dirakit dibawa ke perairan untuk melakukan pemasangan alat tangkap. Pemasangan alat tangkap dilakukan dengan menancapkan patok ke dasar perairan, lalu alat tangkap diikatkan pada patok yang telah ditancapkan dan diturunkan pada kisaran 
kedalaman 1-2 meter, 2-3 meter dan 4-6 meter dengan panjang alat tangkap 50 meter.

Lobster yang telah bertelur menetas menjadi benih akan terbawa arus dan menempel di alat tangkap tersebut. Alat tangkap pocong yang di pasang didiamkan atau direndam selama 10 hari sampai berlumut, kemudian selang 10 hari tersebut alat tangkap pocong sudah mulai dicek dengan cara mengangkat rumpon (shelter) dari dalam air untuk mengumpulkan benih lobster yang menempel di sela-sela alat tangkap tersebut.

Pengambilan sampel benih lobster dilakukan sebanyak 4 (empat) kali pengambilan sampel dengan selisih waktu 2 minggu pengambilan sampel pertama dengan pengambilan sampel berikutnya, dengan cara mengangkat alat tangkap pocong dari dalam air kemudian mengumpulkan benih lobster yang menempel di sela-sela alat tangkap lalu digantungkan kembali. Hasil yang didapatkan selanjutnya dipilah dan diidentifikasi berdasarkan jumlah individu per jenis yang tertangkap menggunakan buku identifikasi WWF Indonesia (2015). Data yang didapatkan kemudian diolah dan dianalisis untuk mengetahui hubungan kelimpahan benih lobster berdasarkan kedalaman dalam bentuk tabel dan dikorelasikan.

Pengukuran kualitas perairan dilakukan secara langsung dan digambarkan secara deskriptif yaitu sebanyak 3 kali ulangan pada tiap stasiun pengamatan yang bertujuan untuk mengetahui kondisi perairan habitat benih lobster, sedangkan pengukuran nilai DO (oksigen terlarut) dilakukan dengan cara mengambil sampel air pada tiap stasiun penelitian, kemudian dianalisis di Laboratorium Perikanan dan Ilmu Kelautan.

Perhitungan kelimpahan benih lobster dilakukan dengan menggunakan indeks kelimpahan relatif menurut Odum (1971), yaitu:

$\mathrm{KR}=\frac{\mathrm{ni}}{\mathrm{N}} \times 100 \%$

Keterangan :

$\mathrm{KR}=$ Kelimpahan Relatif species

$\mathrm{ni}=$ Jumlah individu spesies ke-i

$\mathrm{N}=$ Jumlah total individu spesies

Pengolahan analisis hubungan

kelimpahan benih lobster dengan kedalaman menggunakan rumus Sugiyono (2007), yaitu:

$\mathrm{r}=\frac{\mathrm{N} \Sigma \mathrm{XY}-(\Sigma \mathrm{X})(\Sigma \mathrm{Y})}{\sqrt{\mathrm{N} \Sigma \mathrm{X}^{2}}-(\Sigma \mathrm{X})^{2}\left(\mathrm{~N} \sum \mathrm{Y}^{2}-\left(\Sigma \mathrm{Y}^{2}\right)\right.}$

Keterangan :

$\mathrm{R}=$ Koefisien korelasi
$\mathrm{X}=$ Variabel yang diukur

$\mathrm{N}=$ Jumlah total sampel

$\mathrm{Y}=$ Variabel yang diukur

Hasil yang diperoleh disesuaikan dengan pedoman interpretasi terhadap koefisien korelasi menurut Sugiyono (2007) disajikan pada Tabel 2.

Tabel 2. Kriteria Koefisien Korelasi

\begin{tabular}{cc}
\hline $\begin{array}{c}\text { Interval Koefisien } \\
\text { Korelasi }\end{array}$ & $\begin{array}{c}\text { Tingkat } \\
\text { Hubungan }\end{array}$ \\
\hline $0,00-0,199$ & Sangat rendah \\
$0,20-0,399$ & Rendah \\
$0,40-0,599$ & Sedang \\
$0,60-0,799$ & Kuat \\
$0,80-1,00$ & Sangat kuat \\
\hline
\end{tabular}

Hasil dan Pembahasan

Jenis benih lobster yang tertangkap di Perairan Desa Ranooha Raya yaitu jenis benih lobster mutiara ( $P$. ornatus) dan benih lobster pasir ( $P$. homarus), dimana kedua spesies ini termasuk dua dari enam spesies benih lobster di perairan Indonesia. Hal ini sesuai dengan pernyataan Capeleman (2015), bahwa terdapat enam jenis lobster di perairan Indonesia, enam jenis lobster tersebut merupakan jenis yang menghuni perairan tropika, yaitu lobster pasir ( $P$. homarus), lobster batu ( $P$. penicillatus), lobster batik ( $P$. longipes), lobster bambu cokelat ( $P$. polyphagus), lobster bambu hijau $(P$. versicolor $)$ dan lobster mutiara $(P$. ornatus).

Kelimpahan benih lobster pada bulan Mei (minggu 1-3) relatif rendah dan mulai meningkat pada pertengahan bulan Juni (minggu 4), dimana pada waktu tersebut dipengaruhi oleh arah angin dan musim penangkapan benih lobster. Dimana pada bulan 5 (Mei) dipengaruhi oleh musim Utara sehingga angin dan arus lebih cenderung mengarah ke Pelabuhan Lapuko dan masih tersebar kedesa-desa lain, sedangkan pada bulan 6 (Juni) terjadi musim angin Timur yang arah arusnya cenderung mengarah ke Perairan Desa Ranooha Raya. Hal ini dikarenakan terbentuknya puncak kelimpahan benih lobster pada waktu tersebut serta berhubungan erat dengan kondisi dan fenomena oseanografi yang terjadi di sekitar lokasi penelitian. Hal ini sesuai dengan pernyataan Gonzalez dan Wehrtmann (2011), bahwa parameter oseanografi berhubungan erat dengan kondisi dan fenomena yang terjadi di sekitar lokasi penelitian benih lobster. 
Tabel 3. Hasil Analisis Jenis dan Jumlah Benih Lobster (Panulirus spp.)

\begin{tabular}{cccccc}
\hline No. & Jenis Species & $\begin{array}{c}\text { Stasiun I } \\
\text { (individu) }\end{array}$ & $\begin{array}{c}\text { Stasiun II } \\
\text { (individu) }\end{array}$ & $\begin{array}{c}\text { Stasiun III } \\
\text { (individu) }\end{array}$ & Jumlah \\
\hline 1. & Benih lobster mutiara (P. ornatus) & 108 & 147 & 118 & 373 \\
2. & Benih lobster pasir (P. homarus) & 47 & 74 & 65 & 186 \\
\hline & Jumlah & $\mathbf{1 5 5}$ & $\mathbf{2 2 1}$ & $\mathbf{1 8 3}$ & $\mathbf{5 5 9}$ \\
\hline
\end{tabular}

Tabel 4. Hasil Analisis Persentase Kelimpahan Relatif Benih Lobster

\begin{tabular}{|c|c|c|c|c|c|c|c|c|c|}
\hline \multirow{3}{*}{ Stasiun } & \multirow{3}{*}{ Jenis Species } & \multicolumn{8}{|c|}{ KR (\%) } \\
\hline & & \multicolumn{2}{|c|}{ Minggu I } & \multicolumn{2}{|c|}{ Minggu II } & \multicolumn{2}{|c|}{ Minggu III } & \multicolumn{2}{|c|}{ Minggu IV } \\
\hline & & $\mathbf{n}$ & $\%$ & $\mathbf{n}$ & $\%$ & $\mathrm{n}$ & $\%$ & $\mathrm{n}$ & $\%$ \\
\hline \multirow{2}{*}{ I } & $\begin{array}{l}\text { Benih lobster } \\
\text { mutiara } \\
(P . \text { ornatus })\end{array}$ & 15 & 75 & 10 & 66,67 & 10 & 66,67 & 73 & 69,52 \\
\hline & $\begin{array}{l}\text { Benih lobster } \\
\text { pasir } \\
\text { (P. homarus) }\end{array}$ & 5 & 25 & 5 & 33,33 & 5 & 33,33 & 32 & 30,48 \\
\hline \multirow{2}{*}{ II } & $\begin{array}{l}\text { Benih lobster } \\
\text { mutiara } \\
(P . \text { ornatus })\end{array}$ & 23 & 65,71 & 11 & 57,89 & 10 & 58,82 & 103 & 68,67 \\
\hline & $\begin{array}{l}\text { Benih lobster } \\
\text { pasir } \\
\text { (P. homarus) }\end{array}$ & 12 & 34,29 & 8 & 42,11 & 7 & 41,18 & 47 & 31,33 \\
\hline \multirow{2}{*}{ III } & $\begin{array}{l}\text { Benih lobster } \\
\text { mutiara } \\
(P . \text { ornatus })\end{array}$ & 18 & 69,23 & 8 & 44,44 & 10 & 52,63 & 82 & 68,33 \\
\hline & $\begin{array}{l}\text { Benih lobster } \\
\text { pasir } \\
(P . \text { homarus })\end{array}$ & 8 & 30,77 & 10 & 55,56 & 9 & 47,37 & 38 & 31,67 \\
\hline
\end{tabular}

Hasil penelitian kelimpahan individu benih lobster (Panulirus spp.) yang mendominasi perairan Ranooha Raya yaitu pada stasiun II dengan kedalaman 4 meter yang berjumlah 221 individu yang terdiri atas jenis benih lobster mutiara berjumlah 147 individu dan jumlah jenis benih lobster pasir 74 individu. Hal ini dipengaruhi oleh pergerakan arah arus perairan yang lebih cenderung mengarah ke stasiun II bagian Timur, karena sifatnya yang masih planktonik sehingga pergerakannya dipengaruhi oleh arus. Selain itu, benih lobster lebih menyukai substrat dasar perairan berpasir untuk melakukan perlindungan dari predator maupun melakukan pergantian kulit (moulting). Hal ini sesuai dengan pernyataan Thao (2012), bahwa setiap stadia hidup lobster berasosiasi dengan kondisi ekologi yang spesifik dan memperlihatkan daya adaptasi yang nyata dari lobster. Larva phyllosoma mengapung pada permukaan air dan akan terbawa oleh gelombang, arus, dan angin.

Berdasarkan hasil penelitian persentase kelimpahan relatif jenis benih lobster (Panulirus spp.) tertinggi yaitu jenis benih lobster mutiara (P. ornatus) sebesar $75 \%$ dibandingkan jenis benih lobster pasir $(P$. homarus) yang hanya sebesar 55,56\%. Hal ini dikarenakan benih lobster mutiara lebih toleran terhadap masing-masing faktor kualitas perairan. Selain itu, karakteristik perairan yang relatif dangkal, terlindung, dan dasar pasir berlumpur dengan tingkat kecerahan sedang hingga tinggi dengan arus tidak terlalu kuat yang umumnya habitat bagi benih lobster mutiara. Hal ini sesuai dengan pernyataan Kemp dan Britz (2008), bahwa $P$. ornatus umumnya hidup pada habitat perairan yang relatif dangkal, terlindung, dasar berlumpur, dengan tingkat kekeruhan sedang hingga tinggi. 
Persentase kelimpahan relatif jenis benih lobster (Panulirus spp.) berdasarkan periode pengamatan mempunyai nilai yang bervariasi dengan kisaran masing-masing antara periode minggu 1-4. Persentase kelimpahan relatif jenis tertinggi yaitu pada stasiun I minggu pertama jenis benih lobster mutiara $(P$. ornatus) yaitu $75 \%$ dan persentase kelimpahan relatif jenis benih lobster pasir tertinggi yaitu pada stasiun III minggu kedua yaitu 55,56\%, sedangkan jenis benih lobster mutiara terendah yaitu pada stasiun II minggu keempat sebesar 44,44 \% dan jenis benih lobster pasir terendah yaitu stasiun I minggu pertama sebesar $25 \%$. Hal ini dikarenakan pengambilan sampel disetiap periode terdapat periode musim penangkapan serta faktor parameter kualitas perairan yang mendukung keberadaan benih lobster di perairan. Dimana kondisi lingkungan perairan, juga sangat dipengaruhi oleh pergerakan arus dan angin. Hal ini sesuai dengan per nyataan Rios-Lara et al., (2007), bahwa arus sangat berperan penting di dalam sebaran larva. Didukung oleh Phillips (2006), bahwa kondisi kualitas air sangat berperan terhadap keberadaan, pertumbuhan, reproduksi, dan migrasi benih lobster di suatu perairan.

Kelimpahan benih lobster (Panulirus spp.) disetiap stasiun pengamatan yaitu pada stasiun I kedalaman 6 meter minggu 1-4 berkisar antara 25-75\% dengan jumlah 155 individu, stasiun II kedalaman 4 meter berkisar antara 31,33-68,67 \% dengan jumlah 221 individu dan pada stasiun III kedalaman 2 meter minggu 1-4 berkisar antara 30,77 $69,23 \%$ dengan jumlah 183 individu. Dimana kelimpahan tertinggi terdapat pada stasiun II kedalaman 4 meter yang terdiri dari jenis benih lobster mutiara dan benih lobster pasir. Benih lobster dominan tertangkap pada stasiun II kedalaman 4 meter, hal ini dikarenakan arah arus menuju ke stasiun II tersebut. Selain itu, sifat benih lobster yang masih planktonik sehingga pergerakannya dipengaruhi oleh arah arus perairan dan sifat benih lobster yang suka mencari tempat perlindungan untuk bersembunyi dari predator maupun mencari tempat yang terdapat sumber makanan serta banyaknya alat tangkap yang terpasang pada stasiun II sehingga memungkinkan benih lobster melakukan persembunyian. Hal ini sesuai dengan pernyataan Pratiwi (2013), bahwa lobster yang telah bertelur menetas menjadi benih akan terbawa arus. Puerulus dapat berenang bebas dan berpindah ke daerah dimana terdapat makanan dan dapat terhindar dari predator.

Berdasarkan pengamatan secara morfologi jenis benih lobster mutiara $P$. ornatus memiliki permukaan bagian atas ruas abdomen dengan alur melintang berbentuk lurus dan bagian tepi bergerigi. Memiliki warna dasar kecoklatan dengan bintik-bintik terang tersebar diseluruh permukaan tubuh dan pada bagian ujung antena terdapat bulatbulat hitam. Hal ini sesuai dengan pernyataan Yusnaeni et al., (2009), bahwa lobster mutiara memiliki warna dasar biru kehijauan sampai biru kekuningan. Pada bagian segmen abdomen berwarna kegelapan pada bagian tengah dan bagian sisi mempunyai bercak putih. Berdasarkan pengamatan secara morfologi jenis benih lobster pasir $P$. homarus memiliki warna dasar kekuningan pada bagian segmen abdomen. Berwarna kegelapan pada bagian tengah dan bagian sisi mempunyai bercak putih dan kaki-kakinya. Hal ini sesuai dengan pernyataan Yusnaeni $e t$ al., (2009), bahwa Lobster ini mempunyai warna dasar kehijauan atau kecoklatan dengan dihiasi bintik-bintik terang tersebar di seluruh permukaan segmen abdomen dan kaki bercakbercak putih.

Berdasarkan hasil analisis data diperoleh nilai koefisien korelasi yakni 0,6175-0,988, hal ini memberikan gambaran bahwa terdapat hubungan yang kuat antara variabel bebas yakni kedalaman perairan dengan variabel terikat yakni kelimpahan benih lobster (Panulirus spp.). Dimana kelimpahan benih lobster dominan tertangkap pada kedalaman 4 meter. Hal ini dikarenakan sifatnya yang masih planktonik dan pergerakannya dipengaruhi oleh arus sehingga mudah terbawa oleh arus kearah pesisir pantai maupun kedalaman tertentu. Selain itu, benih lobster bersifat suka mencari tempat perlindungan yang terdapat makanan salah satunya lumut yang menempel pada alat tangkap pocong (shelter). Serta adanya pengaruh faktor fisika-kimia perairan seperti angin, arus, gelombang, suhu, DO, salinitas, dan $\mathrm{pH}$. Hal ini sesuai dengan pernyataan Erlania et al., (2014), bahwa setiap jenis lobster mendiami kedalaman tertentu berdasarkan jenis spesies, serta pengaruh gelombang dan angin yang kuat dapat membawa benih lobster ke arah pesisir maupun kedalaman tertentu. 
Tabel 5. Hasil Analisis Korelasi Hubungan Kelimpahan Benih Lobster (Panulirus spp.) berdasarkan Kedalaman

\begin{tabular}{|c|c|c|c|c|c|c|c|c|}
\hline Stasiun & $\mathrm{x} .1$ & y.1 & x. 2 & y. 2 & x.3 & y.3 & $\mathrm{x.4}$ & y.4 \\
\hline \multirow{2}{*}{ I } & \multirow{2}{*}{6,05} & 75 & \multirow{2}{*}{6,21} & 66,67 & \multirow{2}{*}{6,26} & 66,67 & \multirow{2}{*}{6} & 69,52 \\
\hline & & 25 & & 33,33 & & 33,33 & & 30,48 \\
\hline \multirow{2}{*}{ II } & \multirow{2}{*}{4,03} & 65,71 & \multirow{2}{*}{4,14} & 57,89 & \multirow{2}{*}{4,17} & 58,82 & \multirow{2}{*}{4} & 68,67 \\
\hline & & 34,29 & & 42,11 & & 41,18 & & 31,33 \\
\hline \multirow{2}{*}{ III } & \multirow{2}{*}{2,03} & 69,23 & \multirow{2}{*}{2,32} & 44,44 & \multirow{2}{*}{2,39} & 52,63 & \multirow{2}{*}{2} & 68,33 \\
\hline & & 30,77 & & 55,56 & & 47,37 & & 31,67 \\
\hline \multicolumn{2}{|c|}{ Korelasi (r) } & 0,6175 & & 0,9875 & & 0,9997 & & 0,9688 \\
\hline \multicolumn{2}{|c|}{ Hubungan } & Kuat & & $\begin{array}{c}\text { Sangat } \\
\text { kuat }\end{array}$ & & $\begin{array}{c}\text { Sangat } \\
\text { kuat }\end{array}$ & & $\begin{array}{c}\text { Sangat } \\
\text { kuat }\end{array}$ \\
\hline
\end{tabular}

Tabel 6. Hasil Pengukuran Parameter Kualitas Perairan per Minggu

\begin{tabular}{|c|c|c|c|c|}
\hline \multirow[t]{2}{*}{ No. } & \multirow[t]{2}{*}{ Parameter } & \multicolumn{3}{|c|}{ Stasiun } \\
\hline & & $\mathbf{I}$ & II & III \\
\hline \multirow[t]{4}{*}{1.} & Kedalaman (m) & 6,05 & 4,03 & 2,05 \\
\hline & & 6,21 & 4,14 & 2,32 \\
\hline & & 6,26 & 4,17 & 2,39 \\
\hline & & 6 & 4 & 2 \\
\hline \multirow[t]{4}{*}{2.} & Suhu $\left({ }^{\circ} \mathrm{C}\right)$ & 30 & 31 & 31 \\
\hline & & 29 & 29 & 29 \\
\hline & & 28 & 29 & 29 \\
\hline & & 31 & 32 & 32 \\
\hline \multirow[t]{4}{*}{3.} & Kecerahan (\%) & 75 & 87 & 100 \\
\hline & & 66 & 70 & 72 \\
\hline & & 66 & 69 & 70 \\
\hline & & 74 & 87 & 100 \\
\hline \multirow[t]{4}{*}{4.} & Kecepatan Arus (m/s) & 0,06 & 0,07 & 0,08 \\
\hline & & 0,07 & 0,08 & 0,10 \\
\hline & & 0,07 & 0,08 & 0,09 \\
\hline & & 0,07 & 0,09 & 0,08 \\
\hline \multirow[t]{4}{*}{5.} & Salinitas (\%o) & 33 & 31 & 31 \\
\hline & & 30 & 29 & 29 \\
\hline & & 30 & 30 & 29 \\
\hline & & 34 & 32 & 31 \\
\hline \multirow[t]{4}{*}{6.} & $\mathrm{pH}$ & 7 & 7 & 7 \\
\hline & & 7 & 7 & 7 \\
\hline & & 7 & 7 & 7 \\
\hline & & 7 & 7 & 7 \\
\hline \multirow[t]{4}{*}{7.} & DO (mg/L) & 5,7 & 4,9 & 6,2 \\
\hline & & 4,9 & 5,3 & 5,7 \\
\hline & & 5,7 & 5,3 & 5,3 \\
\hline & & 6,6 & 4,9 & 6,2 \\
\hline
\end{tabular}

Berdasarkan hasil penelitian parameter lingkungan di perairan Desa Ranooha Raya yaitu masih mendukung untuk kehidupan, pertumbuhan dan perkembangan benih lobster (Panulirus spp.), diantaranya kecerahan, kedalaman, suhu, kecepatan arus, kedalaman, salinitas, $\mathrm{pH}$ dan DO (oksigen terlarut). Dimana parameter ini sangat mempengaruhi keberadaan, pertumbuhan, reproduksi, dan migrasi benih lobster di suatu perairan. Hal 
ini sesuai dengan pernyataan Thangaraja dan Radhakrishnan (2012), bahwa parameter lingkungan merupakan faktor pembatas dari distribusi setiap spesies lobster. Setiap spesies memiliki habitat dengan karakteristik yang spesifik sesuai kebutuhannya terkait ketersediaan makanan, tempat berlindung, dan reproduksinya.

Suhu juga merupakan faktor penting yang sangat mendukung kehidupan biota dalam perairan seperti benih lobster. Hasil penelitian diperoleh kisaran suhu perairan yaitu $28-32{ }^{\circ} \mathrm{C}$, kisaran ini cukup baik untuk kehidupan benih lobster (Panulirus spp.) dimana perkembangan larva dan post larva dari lobster sangat sensitif terhadap perubahan suhu perairan. Hal ini sesuai dengan pernyataan Purnamaningtyas dan Nurfiani (2017), bahwa suhu mempengaruhi pertumbuhan juvenil spiny lobster dan spiny lobster dewasa. Lobster dapat tumbuh dengan baik pada perairan dengan suhu hangat daripada perairan dengan suhu dingin.

Kecerahan merupakan tingkat intensitas cahaya matahari yang menembus suatu perairan, sehingga hal ini sangat dipengaruhi oleh kekeruhan. Berdasarkan hasil penelitian tingkat kecerahan yang telah dilakukan diperoleh nilai kecerahan sebesar 66-100 \%, dimana kecerahan mempengaruhi kehidupan benih lobster (Panulirus spp.) di lingkungan perairan tersebut khususnya benih $P$. ornatus yang lebih menyukai daerah yang dangkal dan sedikit keruh. Selain itu, secara pengamatan visual yang dilakukan terhadap substrat dasar daerah lokasi studi menunjukkan bahwa pecahan karang, pasir dan berlumpur merupakan substrat dasar yang dominan. Hal ini sesuai dengan pernyataan Hamuna et al., (2018), bahwa tingkat kecerahan dan kekeruhan air laut sangat berpengaruh pada pertumbuhan biota laut. Tingkat kecerahan air laut sangat menentukan tingkat fotosintesis biota yang ada di perairan laut.

Kecepatan arus merupakan faktor yang sangat mempengaruhi keberadaan benih lobster (Panulirus spp.) di daerah sekitar pesisir karena sifatnya yang masih planktonik sehingga mudah terbawa oleh arus. Berdasarkan penelitian yang telah dilakukan diperoleh kecepatan arus berkisar antara 0,06$0,08 \mathrm{~m} / \mathrm{s}$, hal ini masih tergolong arus yang tidak terlalu kuat sehingga kelimpahan benih lobster banyak ditemukan pada stasiun II karena didukung oleh pergerakan arus perairan. Hal ini sesuai dengan pernyataan Rios-Lara et al., (2007), bahwa arus memengaruhi sebaran dari larva, karena diduga benih lobster yang tersebar dan berkembang pada suatu lokasi dapat berasal dari larva yang terbawa oleh arus dari lokasi yang berbeda, sedangkan pendapat lainnya menyatakan arus yang berlawanan dapat mengembalikan larva ke lokasi asalnya.

Salinitas merupakan salah satu parameter lingkungan yang mempengaruhi proses biologi dan secara tidak langsung akan mempengaruhi kehidupan organisme yaitu mempengaruhi laju pertumbuhan, jumlah makanan dan daya kelangsunan hidup. Berdasarkan hasil pengukuran salinitas disetiap stasiun pengamatan berkisar antara 29-34 \%o. Dimana nilai salinitas pada kisaran ini masih mendukung untuk kehidupan benih lobster di perairan. Yakni benih lobster lebih menyukai daerah dengan salinitas yang lebih rendah yaitu 29-31\% untuk mendukung proses pergantian kulitnya sebelum mencapai fase juvenil untuk itu kelimpahan benih lobster banyak ditemukan pada stasiun II dan III. Hal ini sesuai dengan pernyataan Rahman dan Mansyur (2016), bahwa salinitas merupakan salah satu parameter kualitas air yang penting untuk kelangsungan hidup suatu organisme.

Hasil pengukuran $\mathrm{pH}$ secara in situ disetiap stasiun pengamatan tidak terdapat perbedaan yakni nilai $\mathrm{pH} \quad 7$ yang mengindikasikan bahwa perairan Ranooha Raya bersifat netral dan mendukung untuk kehidupan organisme laut khususnya benih lobster yang berasosiasi di perairan tersebut. $\mathrm{pH}$ perairan sangat berpengaruh terhadap tingkat kesuburan suatu perairan karena mempengaruhi kehidupan organisme laut. Hal ini sesuai dengan pernyataan Megawati et al., (2014), bahwa variasi nilai $\mathrm{pH}$ perairan sangat mempengaruhi biota disuatu perairan, $\mathrm{pH}$ air normal adalah 7,2-8,1. Dengan kisaran $\mathrm{pH}$ air yang demikian, dikatakan masih layak untuk semua kebutuhan hidup organisme perairan .

Berdasarkan hasil analisis nilai DO (oksigen terlarut) yang didapatkan berada pada kisaran 4,9-6,6 $\mathrm{mg} / \mathrm{L}$. Hal ini mengindikasikan bahwa nilai DO pada Perairan Ranooha Raya memiliki kualitas yang bagus untuk kehidupan benih lobster. Dimana semakin besar nilai DO pada air, mengindikasikan air tersebut memiliki kualitas yang bagus, sebaliknya jika nilai DO 
rendah dapat diketahui bahwa air tersebut telah tercemar. Hal ini sesuai dengan pernyataan Gemilang et al., (2017), bahwa DO dibutuhkan oleh semua jasad hidup untuk pernapasan, proses metabolisme atau pertukaran zat yang kemudian menghasilkan energi untuk pertumbuhan dan pembiakan, selain itu sejauh mana badan air mampu menampung biota air seperti ikan dan mikroorganisme.

\section{Kesimpulan}

Berdasarkan hasil penelitian dapat disimpulkan bahwa:

1. Jenis benih lobster mutiara ( $P$. ornatus) dan jenis benih lobster pasir ( $P$. homarus) banyak ditemukan melimpah pada stasiun II kedalaman 4 meter, persentase kelimpahan tertinggi pada kedalaman 6 meter minggu pertama jenis benih lobster mutiara dan jenis benih lobster pasir tertinggi pada kedalaman 4 meter minggu keempat.

2. Terdapat hubungan yang kuat antara persentase kelimpahan relatif benih lobster dengan kedalaman perairan.

3. Kecepatan arus merupakan faktor yang sangat mempengaruhi keberadaan benih lobster (Panulirus spp.) di perairan.

\section{Daftar Pustaka}

Capeleman. 2015. Southeast Asia Crustacean and Mollusca Identification. (Online). Tersedia

Laman:http://capeleman.blogspot.com/ p/southeast-asia-crustacean-andmollusca.html. Diakses pada Tanggal 15 April 2015.

Erlania, Radiarta, N. dan Sugama, K. 2014. Dinamika Kelimpahan Benih Lobster (Panulirus spp.) di Perairan Teluk Gerupuk, Nusa Tenggara Barat:Tantangan Pengembangan Teknologi Budidaya Lobster. Jurnal Ris. Akuakultur Vol. 9 (3): 475-486.

Gemilang, W.A., dan Kusumah, G. 2017. Status Indeks Pencemaran Perairan Kawasan Mangrove Berdasarkan Penilaian Fisika-Kimia di Pesisir Kecamatan Brebes Jawa Tengah. Enviroscienteae, 13(2), 171-180.

Gonzalez, O., dan Wehrtmann, I.S. 2011. Postlarval settlement of spiny lobster, Panulirus argus (Latreille, 1804) (Decapoda: Palinuridae), at the
Caribbean coast of Costa Rica.Lat. Am. J. Aquat. Res., 39(3), 575-583.

Hamuna, B., Tanjung, R.H.R., Suwito., Maury, H.K. dan Alianto. 2018. Kajian Kualitas Air Laut dan Indeks Pencemaran Berdasarkan Parameter Fisika-Kimia di Perairan Distrik Depapre, Jayapura. Jurnal Ilmu Lingkungan, Vol. 16 (1) : 35-43.

Kemp, J.O.G. dan Britz, P.J. (2008). The effect of temperature on the growth, survival and food consumption of the east coast rock lobster Panulirus homarus rubellus. Aquaculture, 280, 227-231.

Megawati, C., Yusuf, M., dan Maslukah, L. 2014. Sebaran Kualitas Perairan Ditinjau dari Zat Hara, Oksigen Terlarut dan $\mathrm{pH}$ di Perairan Selatan Bali Bagian Selatan. Jurnal Oseanografi, Vol. 3(2): 142-150.

Odum, E.P. 1971. Dasar-dasar Ekologi. Diterjemahkan oleh: T. Samingan dan B. Sringandono. Fundamental of Ecology. Gadjah Mada University Press.

Phillips, B.F. 2006. Lobsters: biology, management, aquaculture, and fisheries. Blackwell Publishing Ltd., $506 \mathrm{pp}$.

Pratiwi, R. 2013. Lobster Komersial (Panulirus spp.). Jurnal Oseana, Vol. 38 (2): 55-68.

Purnamaningtyas, S.E. dan Nurfiani, A. 2017. Kebiasaan Makan Beberapa Spiny Lobster di Teluk Gerupuk dan Teluk Bumbang, Nusa Tenggara Barat.

Rahman, A. dan Mansyur, A. 2016. Kesesuaian Pemanfaatan Perairan bagi Pengembangan Perikanan Budidaya di Kawasan Teluk Staring Konawe Selatan. Jurnal Bisnis Perikanan FPIK UHO, Vol. 3(1): 2355-6617.

Rios-Lara, V., Salas, S., Javier, B.P., \& IreneAyora, P. 2007. Distribution patterns of spiny lobster (Panulirus argus) at Alacranes reef, Yucatan: Spatial analysis and inference of preferential habitat. Fisheries Research, 87,35-45.

Saputra S W. 2009. Status Pemanfaatan Lobster (Panulirus sp.) di Perairan Kebumen. Jurnal Saintek Perikanan. 4(2): 10-15.

Thangaraja, R. dan Radhakrishnan, E.V. 2012. Fishery and ecology of the spiny 
lobster Panulirus homarus (Linnaeus, 1758) at Khadiyapatanam in the southwest coast of India. J. Mar. Biol. Ass. India, 54(2), 69-79.

Thao, N.T.K. 2012. Opportunities and challenges in lobster marine aquaculture in Viet Nam: The case of Nha Trang Bay. Thesis. The Norwegian College of Fishery Science University of Tromso, Norway \& Nha Trang University. Vietnam, $66 \mathrm{pp}$.

WWF Indonesia. 2015. Perikanan Lobster Laut-Panduan Penangkapan dan Penanganan. Sustainable Seafood. Jakarta Selatan.

Yusnaini, M. N., Nessa, M. I., Djawad, D.D. dan Trijuno. 2009. Ciri Morfologi Jenis Kelamin dan Kedewasaan Lobster Mutiara (Panulirus ornatus). Jurnal Ilmu Kelautan dan Perikanan, Vol. 19 (3): 166-74. 